ABDIRA Volume 2 Nomor 1 Tahun 2022 Halaman 7-12

JURNAL PENGABDIAN MASYARAKAT

Research \& Learning in Faculty of Education

\title{
Pelatihan Penyusunan Rencana Perjalanan Berbahasa Mandarin di SMK Taman Siswa Purwokerto
}

\author{
Destynisa Tazkiyah ${ }^{1}$, Zuyinatul Isro2 ${ }^{2}$, Berliana Cantika Putri ${ }^{3}$ \\ Program Studi D-3 Bahasa Mandarin, Universitas Jenderal Soedirman \\ e-mail: destyanisa.tazkiyah@unsoed.ac.id ${ }^{1}$, zuyinatul.isro@unsoed.ac.id² ${ }^{2}$, \\ berliana.putri@mhs.unsoed.ac.id ${ }^{3}$
}

\begin{abstract}
Abstrak
Sebagai bentuk pelayanan di bidang pariwisata pengabdian ini bertujuan untuk mempersiapkan calon lulusan SMK Taman Siswa jurusan pariwisata agar memiliki kemampuan dasar penyusunan rencana perjalanan wisata bagi turis Tiongkok. Jumlah wisatawan Tiongkok menduduki peringkat kedua terbanyak ssetelah Malaysia berdasarkan data BPS pada akhir tahun 2019 sebelum pandemi Covid, hal ini harus diimbangi dengan peningkatan pelayanan atau hospitality yang baik. Salah satunya yaitu dengan upaya pemberdayaan SDM pariwisata yang mampu berbahasa Mandarin. Kegiatan pengabdian ini adalah salah satu upaya yang dapat mempersiapkan para siswa untuk siap terjun di dunia pariwisata, baik di masa pandemi new normal atau pun jika keadaan telah kembali normal. Metode yang digunakan pada pelaksanaan kegiatan ini adalah metode pendampingan. Hasil dari kegiatan pelatihan ini para siswa berhasil mempelajari Bahasa Mandarin dasar di bidang pariwisata, serta mampu menyusun rencana perjalanan khas Banyumas berbahasa Mandarin berbasis new normal pandemi Covid-19.
\end{abstract}

Kata Kunci: pariwisata, bahasa Mandarin, rencana perjalanan

\begin{abstract}
As a form of service in the field of tourism, this community service aims to prepare prospective graduates of the Taman Siswa Vocational School majoring in tourism to have basic skills in preparing travel plans for Chinese tourists. The number of Chinese tourists ranked second after Malaysia based on BPS data at the end of 2019 before the Covid pandemic, this must be balanced with an increase in good service or hospitality. One of them is by empowering tourism human resources who are able to speak Mandarin. This service activity is one of the efforts that can prepare students to be ready to enter the world of tourism, both during the new normal pandemic or when things have returned to normal. The method used in the implementation of this activity is the mentoring method. As a result of this training activity, the students succeeded in learning basic Mandarin in the tourism sector, and were able to develop a typical Banyumas travel plan in Mandarin based on the new normal of the Covid-19 pandemic.
\end{abstract}

Keyword: tourism, Chinese language, itinerary 


\section{PENDAHULUAN}

Adanya Pandemi Covid-19 menyebabkan kerugian di berbagai sektor, salah satu sektor yang merugi adalah sektor pariwisata. Berdasarkan situs Kata Data, Indonesia berpotensi kehilangan devisa hingga $\mathrm{Rp} 54,8$ triliun akibat ditutupnya rute kedatangan dari luar negeri, salah satunya dari Tiongkok. Pemerintah merupakan pihak yang memiliki andil besar dalam pemulihan pariwisata, karena pemerintah dianggap memiliki seluruh sumber daya yang dibutuhkan seperti soal biaya dan kebijakan (Riadil, 2020). Dampak pandemi dapat diminimalisir dan dipulihkan oleh pemerintah baik pusat maupun daerah salah satunya dengan membuat kebijakan dan bekerjasama terkait pembatasan aktivitas yang tentunya akan sangat berimbas pada aktivitas pariwisata (Herdiana, 2020). Realitanya sektor pariwisata menyerap investasi , tenaga kerja serta pengembangan usaha yang tersebar di berbagai pelosok wilayah di Indonesia. Keterkaitan sektor pariwisata terhadap sektor ekonomi lain, seperti hotel, restoran, angkutan, industri kerajinan dan lain-lain semakin membuat sektor ini berpengaruh pada perekonomian nasional (Fong, 2021). Kedepannya dapat terjadi multiplier fect apabila sektor pariwisata terus terpuruk.

Beberapa kebijakan baru telah diterapkan oleh pemerintah guna membangkitkan kembali sektor pariwisata di tengah pandemi. Sebagai upaya mengatasi defisit ekonomi dan peningkatan jumlah pengangguran yang begitu besar, pemerintah memberlakukan kebijakan kenormalan baru (new normal) di tengah pandemi Covid-19. Di era new normal masyarakat bisa kembali melakukan aktivitas ekonomi, sosial dan kegiatan publik secara terbatas dengan tetap menggunakan Protokol Kesehatan pandemi Covid 19 (Hardianto, 2021). Pelonggaran PSBB new normal membuat aktivitas wisata mulai bangkit lagi, tempat-tempat wisata sudah kembali dibuka tetapi dengan menerapkan protokol kesehatan yang ketat. Wisatawan di era New Normal tidak bisa berwisata secara berkelompok dan berkunjung ke tempat wisata yang cenderung ramai. Sehingga tempat wisata yang ada mulai menawarkan konsep ketenangan dan keselamatan serta jauh dari kerumunan sehingga wisatawan menjadi lebih aman dalam berwisata.

Bangkitnya kembali sektor pariwisata di tengah pandemi ini selain merupakan kabar baik pagi para pelaku wisata juga merupakan tantangan, karena para pelaku wisata diharuskan memberikan pelayanan serta promosi pariwisata yang sesuai dengan protokol kesehatan. Hal ini juga menjadi materi penting yang harus dikuasai oleh para calon lulusan di bidang pariwisata. Kemampuan pelayanan dan penyediaan pariwisata di masa pandemi menjadi salah satu bidang yang harus dikuasi oleh para lulusan saat ini dan di masa yang akan datang. SMK Taman Siswa Purwokerto merupakan salah satu sekolah menengah kejuruan yang tengah mempersiapkan materi terbarukan yang berkaitan dengan penanggulangan pariwisata di masa pandemi bagi para anak didiknya. 
SMK Taman Siswa merupakan bagian dari Binaan Kantor cabang dinas pendidikan wilayah X Propinsi Banyumas. Lokasi lembaga pendidikan ini sangat strategis yaitu di wilayah Kabupaten Banyumas bagian utara, berada di antara lalulintas jalur wisata Banyumas Purbalingga tepatnya di Jalan Sunan Ampel Kedungmalang Sumbang Banyumas. Sekolah ini memiliki 3 Jurusan atau program keahlian yaitu perhotelan, usaha perjalanan wisata, dan perbankan dan keuangan mikro. Sistem kegiatan belajar pun juga sangat bervariasi, yaitu adanya kegiatan belajar di kelas dan kegiatan belajar di luar kelas atau outdoor activity sebagai wacana penambahan ketrampilan, wawasan dan pengetahuan.

Rumusan masalah dalam kegiatan pengabdian ini adalah bagaimana upaya pemberian pelatihan penyusunan rencana perjalanan khas Banyumas berbahasa Mandarin bagi para siswa jurusan pariwisata di SMK Taman Siswa. Pemberian pelatihan ini bertujuan untuk menjadi persiapan bagi para calon lulusan untuk siap terjun di dunia pariwisata, baik di masa pandemi new normal atau pun jika keadaan telah kembali normal. Rencana perjalanan dengan objek wisata khas Banyumas dengan berbasis protokol kesehatan menjadi tema utama yang akan menjadi materi pelatihan.

Pelatihan Bahasa Mandarin yang diberikan diupayakan bisa menjadi bekal bagi para siswa untuk memberikan pelayanan pariwisata bagi turis Tiongkok. Materi pelatihan diberikan dengan pembelajaran interaktif. Pembelajaran interaktif mengacu pada interaksi antara peserta didik dengan peserta pendidik, peserta didik dengan pengajar, atau peserta didik dengan media/sumber belajar (Dasna, 2015). Pelaksanaan pelatihan selain menggunakan metode individual-learning juga menerapkan metode cooperative-learning. Model pembelajaran kelompok atau cooperative learning dapat meningkatkan interaksi antar siswa, dengan ditambahnya materi mengandung unsur khas Banyumas dapat menambah antusiasme siswa dalam belajar bahasa Mandarin. Metode cooperative learning ini diterapkan melalui kelompok kecil yang anggotanya terdiri dari siswa yang berbeda (heterogen) baik dalam kemampuan akademik, jenis kelamin dan etnis (Rofiq, 2012).

Materi pelatihan yang disusun mencakup empat kompetensi utama yaitu critical thinking (berpikir kritis), creativity (kreativitas), collaboration (kolaborasi atau bekerja sama), dan communication (komunikasi). Ketrampilan 4-C ini wajib dikuasai dan dimiliki oleh setiap peserta didik guna menghadapai tantangan abad ke-21 (Zubaidah, 2018:3). Guna mencapai kompetensi ini dalam penyusunan rencana perjalanan berbahasa Mandarin maka diusunglah tema khas Banyumas, tema dengan unsur budaya yang dekat dan lekat bagi para peserta didik. Unsur budaya merupakan salah satu metode pembelajaran Bahasa (Syairi, 2013:5).

Dilaksanakannya kegiatan pengabdian ini bertujuan untuk mempersiapkan calon lulusan SMK Taman Siswa jurusan pariwisata agar memiliki kemampuan dasar penyusunan rencana perjalanan wisata bagi turis Tiongkok. Terbentuknya rencana perjalanan wisata atau itinerary yang 
diintegrasikan dengan kearifan lokal budaya Banyumas dan berbahasa Mandarin adalah sebagai salah satu bentuk pelayanan bagi para turis asing.

\section{METODE}

Metode yang dilakukan adalah memberikan pelatihan kepada para siswa SMK Taman Siswa Jurusan Pariwisata. Kegiatan pengabdian dimulai dengan penyusunan materi pembelajaran Penyusunan Rencana Perjalanan Khas Banyumas Berbahasa Mandarin (班优马斯旅游线路) yang relevan dengan pembelajaran bahasa Mandarin serta kondisi new normal pandemic Covid-19 saat ini. Selanjutnya adalah pelatihan langsung pada para siswa, dilakukan secara interaktif dengan penambahan media gambar, video, power point dan pengadaan kuis pre-test dan post-test. Kegiatan di lakukan pada bulan April 2021.

Metode pre-test dan post-test guna mengevaluasi hasil implementasi pelatihan. Pre-test dilaksanakan pada awal pertemuan dengan fokus materi pada bahasa Mandarin tingkat dasar dan materi penyusunan rencana perjalanan dengan butir-butir soal pilihan ganda. Berdasarkan hasil pre-test dilakukan penambahan materi bahan ajar yang sesuai dengan minat dan kemampuan bahasa mahasiswa agar materi pembelajaran menjadi tepat guna. Post-test dilakukan setelah pendampingan guna mengetahui peningkatan hasil belajar siswa.

\section{HASIL DAN PEMBAHASAN}

Kegiatan pelatihan diberikan bagi siswa kelas X, XI, dan XII jurusan pariwisata SMK Taman Siswa. Sosialisasi kepada Kepala Sekolah, guru Bahasa Mandarin dan guru mata pelajaran yang berkaitan dengan kepariwisataan merupakan kegiatan awal yang dilakukkan. Persiapan selanjutnya adalah koordinasi, yang dilakukan antara tim pengabdian dengan, dan guru bahasa Mandarin serta guru pariwisata. Koordinasi dilakukan di antaranya untuk menentukan materi bahan ajar penyusunan rencana perjalanan berbahasa Mandarin yang akan diberikan. Selanjutnya adalah pelaksanaan pre-test, dilanjutkan dengan pemberian pelatihan, yang terakhir adalah pelaksanaan posttest dan evaluasi.

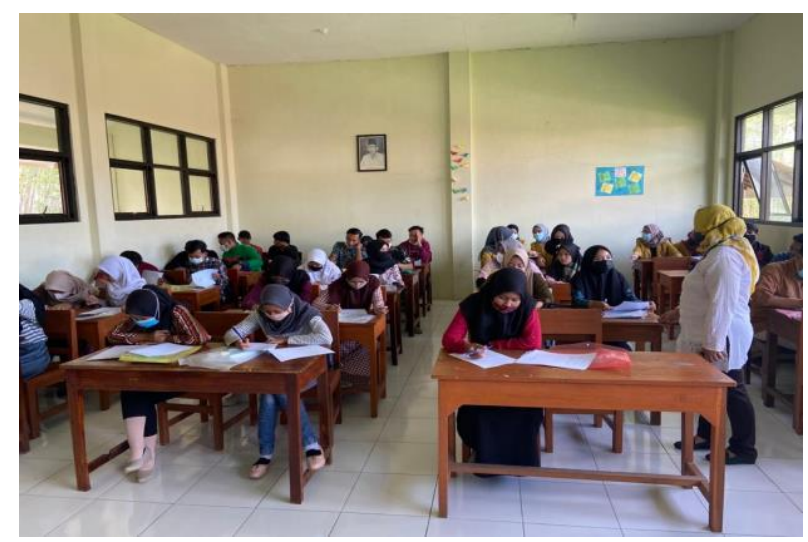

Gambar 1. Pelaksanaan pre-test 
Hasil pre-test menunjukkan 35\% siswa salah dalam menjawab pertanyaan tipe soal menerjemahkan kalimat sambutan wisatawan bahasa Indonesia ke dalam bahasa Mandarin. Kesalahan terdapat dalam susunan tata bahasa, siswa masih terpaku dengan susunan tata bahasa bahasa Indonesia, sedangkan tata bahasa bahasa Indonesia berbeda dengan bahasa Mandarin. Selain kemampuan bahasa Mandarin dalam pre-test juga terdapat soal-soal yang berkaitan dengan materi dasar penyusunan rencana perjalanan. Hasil menunjukkan pengetahuan umum mahasiswa mengenai materi penyusunan rencana perjalanan berbahasa Mandarin belum terlalu baik. Selain itu mahasiswa juga diberi angket yang digunakan sebagai tolok ukur minat mahasiswa dalam materi-materi khas Banyumas yang akan menjadi pembelajaran selama pelatihan.

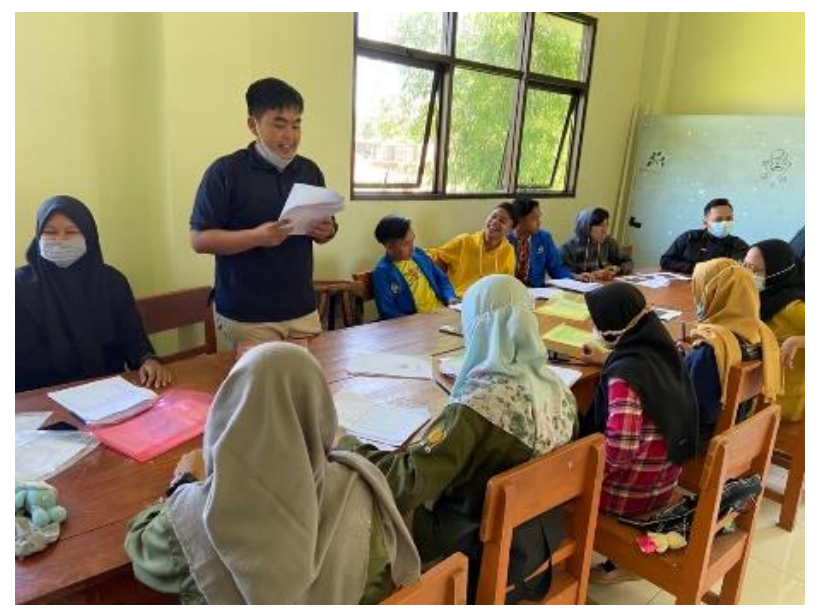

Gambar 2. Pelaksanaan pelatihan Siswa Membacakan Hasil Pekerjaannya

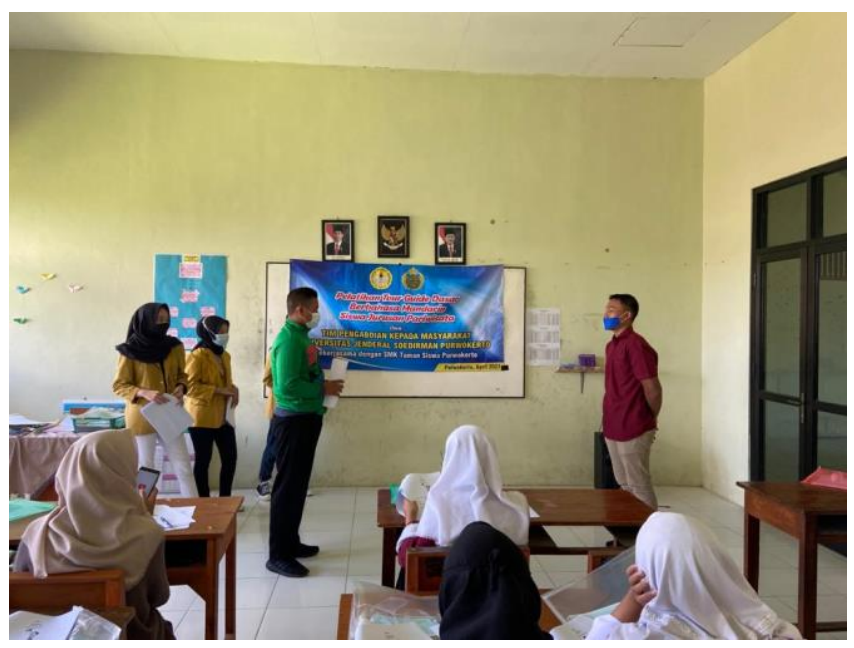

Gambar 3. Pelaksanaan pelatihan para siswa melakukan latiha role play

Tahap selanjutnya adalah pemberian pelatihan kepada para siswa yang diberikan dengan penerapan individual-learning dan cooperative-learning. Dua metode ini diterapkan sebagai upaya pemantapan materi pelatihan. Selain pemaparan materi siswa juga berkesempatan untuk melakukan praktik langsung di ruang kelas serta praktik lapangan di salah satu objek wisata khas Banyumas yang berada di desa Karangsalam, Camp Area Umbul Bengkok. Luaran akhir program pelatihan adalah video role play pemandu wisata dan perencanaan 
perjalanan berbahasa mandarin. Sebelum pelaksanaan praktik lapangan siswa diwajibkan mengerjakan post-test terlebih dahulu guna mengetahui hasil pelatihan yang diberikan. Hasil post-test menunjukkan adanya peningkatan pemahaman para siswa, di mana pada hasil pre-test terdapat 35\% siswa yang memiliki kesalahan sedangkan pada hasil post-test terjadi penurunan hingga $10 \%$ siswa saja.

\section{SIMPULAN}

Pelaksanaan kegiatan pelatihan berjalan dengan lancer, para peserta pelatihan mengikuti kegiatan dari awal hingga selesai degan antusias, tertib, dan mematuhi protokol kesehatan. Melalui kegiatan pelatihan ini para siswa berhasil mempelajari Bahasa Mandarin dasar di bidang pariwisata, serta mampu menyusun rencana perjalanan khas Banyumas berbahasa Mandarin berbasis new normal pandemi Covid-19.

\section{DAFTAR PUSTAKA}

Dasna, I.W.(2015). Modul:Desain dan Model Pembelajaran Inovativ dan Interaktif. Universitas

Terbuka.(online).(https:// repository.ut.ac.id/4324/1/MPDR5203-M!.pdf).

Fong, L. H. N., Law, R., \& Ye, B. H. (2021). Outlook of tourism recovery amid an epidemic: Importance of outbreak control by the government. Annals of Tourism Research, 86, 102951. https:// doi.org/10.1016/j.annals.2020.102951

Hardianto, Willy Tri, dkk.(2021). Strategi Pengelolaan Pariwisata di Masa Covid19 (Studi di Wisata Taman Dolan, Desa Pandanrejo, Kota Batu). Jurnal Ilmiah Manajemen Publik dan Kebijakan Sosial - Vol. 5 No. 1.

Herdiana, D. (2020). Rekomendasi Kebijakan Pemulihan Pariwisata Pasca Wabah Corona Virus Disease 2019 (Covid-19) Di Kota Bandung. Jurnal Master Pariwisata (JUMPA), 1(1), 1-30.

Jaelani, Aceng.(2015). Pembelajaran Kooperatif Sebagai Salah Satu Model Pembelajaran Di Madrasah Ibtidaiyya. IAIAN Syekh Nurjati.(online)(Downloads/189-551-1-PB.pdf).

Riadil, I. G. (2020). Tourism industry crisis and its impacts: investigating the Indonesian tourism employees perspectives' in the pandemic of COVID-19. Jurnal Kepariwisataan: Destinasi, Hospitalitas Dan Perjalanan, 4(2), 98-108.

Rofiq, M.Nafiur. (2012). Cooperative Learning Dalam Pengajaran Pendidikan Agama Islam. Jurnal Falasifa.Vol.1.No.1.

Syairi, Khairi Abu. (2013). Pembelajaran Bahasa dengan Pendekatan Budaya. Jurnal Dinamika Ilmu, Vol.13, No.2, 174-188.

Yuquan, Zhou. (2018). 印尼世界大学华文教育系学生汉语学习动机调查研究.Jurnal Cakrawala Mandarin: Vol.2, No.1, 12-23.

Zubaidah, Siti. (2017). Ketrampilan abad ke-21: Ketrampilan yang Diajarkan Melalui Pembelajaran. Universitas Negeri Malang, 2-17. 